\title{
Correlations of Regional Geotechnical Parameters on the Basis of CPTU and DMT Tests
}

\author{
Tomasz Godlewski ${ }^{1}$, Małgorzata Wszędyrówny-Nast ${ }^{2}$ \\ Department of Geotechnics and Foundation, Building Research Institute, Warsaw, Poland \\ E-mails: ${ }^{1}$ t.godlewski@itb.pl (corresponding author); ${ }^{2}$ m.wszedyrowny@itb.pl
}

\begin{abstract}
The requirements for field research for Polish conditions demand proper dependences. Dependences based on more than 30 localizations for different genetic types of soils were derived for the area of Poland. Direct results from CPT, DMT and profiles from boreholes have been collected at the test sites for individual localization. For interpretation of results, dependences and diagrams of CPTU versus DMT were created. Correlations on the background of results from literature for different types of soils for numerous research areas were collected, with established dependences for Polish grounds conditions. Additionally some recommendations for the interpretation of the results from CPTU and DMT tests for analysed soils have been proposed.
\end{abstract}

Keywords: Local correlations, CPTU, DMT, density or liquidity index, interpretation of modulous.

Conference topic: Geotechnical art and historical experience and Soil and rock investigation.

\section{Introduction}

The requirements of the Eurocode 7 (PN-EN-1997-1 and PN-EN 1997-2) have caused the necessity of quantitative description of soils for geotechnical design. The in situ tests give this opportunity. Their main advantages are commonly known: continuous recording, decreasing the number of laboratory tests and drillings, reduction of total costs and time of investigations. They also allow for determining the soil parameters in natural conditions.

The correlations between sounding results and geotechnical parameters require regional determination or adaptation for local conditions. Additional difficulties refer to many other factors that have an influence on the soil behaviour and which are still impossible to measure, or the measurements are not reliable enough.

The results obtained by means of new types of static probes with cone/piezocone (CPT/CPTU) or flat dilatometer of Marchetti type (DMT) do not have Polish correlations for geotechnical parameters determination, or the existing ones have not been verified yet. The data obtained by foreign researchers refers to local soils and may not be applicable for Polish conditions. The results obtained from soundings are used mainly for geological profile investigations and determination of density or liquidity index of soils. Some geotechnical parameters necessary for design calculations are still assessed on the basis of the $\mathrm{q}_{\mathrm{c}(\mathrm{t})} \rightarrow \mathrm{I}_{\mathrm{D}}, \mathrm{I}_{\mathrm{L}}$ correlation. Many institutions in Poland have started intensive research on interpretation methods of CPT/CPTU and DMT results for determination of geotechnical parameters $\left(\varphi^{\prime}, \mathrm{c}_{\mathrm{u}}, \mathrm{E}_{\mathrm{eod}}\right)$ (Bałachowski et al. 2008; Młynarek et al. 2008, 2013; Rabarijoely, Garbulewski 2013; Godlewski 2015). The aim of the research project (Grant Number 4 T07E 047 30,2008 ) conducted by ITB (Building Research Institute in Warsaw) was to find these correlations.

\section{Investigation methods}

ITB has large experience in in-situ soil investigations by means of cone penetration test and dilatometer test. The huge amount of data, including different types of soils for different types of constructions, has been collected. In the research project (Grant Number 4 T07E 047 30, 2008) the new results were added to the database and statistical calculations were done. Wherever it was possible, the module obtained from in situ tests was compared to the one obtained by back-analysis based on the settlements measurements.

The correlations are based on the results from more than 30 test sites on different types of soils in Poland. Each test site was considered as a node, consisting of CPTU profile, DMT profile, geological profile and settlement data. After extreme values elimination, the data was divided into litho-genetic groups from different test sites.

The following litho-genetic groups were distinguished:

- alluvial deposits of River beds - alluvial sands,

- fluvioglacial deposits - fluvioglacial sands,

- tertiary clays,

- glacial clays (tills of Middle Polish glaciation),

- eolian deposits - loess,

- silty hollow deposits - silty sands, silty tills and silts,

- organic deposits - gyttja, mud (alluvium silt), peat.

All the tests were conducted in accordance with Eurocode 7 and specification for the CPTU and DMT. The tests were carried out very close to each other (within a 2-3 m) on choosen test sites. Because the frequency of measurements for CPTU (each $2 \mathrm{~cm}$ ) and DMT (each $20 \mathrm{~cm}$ ), the results from CPTU were aver- 
aged (from upper and lower surrounding values) to obtain the mean value for each $20 \mathrm{~cm}$. The measured values from these two types of soundings were compared to find correlations in interpretation of the profile, density/liquidity index and modulus.

\section{From the tests results to correlations}

For each type of the soil the $\mathrm{R}_{\mathrm{f}}$ (for CPTU) $\rightarrow \mathrm{I}_{\mathrm{DMT}}$ (DMT material index) were compared. The results were plotted on existing nomograms. The best fitting was obtained on Schmertmann nomogram (Schmertmann 1986) and all further analyses were based on this graph (Fig. 1).

The highest variability was observed for hollow and organic soils. The diversity for hollow soils may be explained by specific sedimentation mechanism which causes high variability in vertical and horizontal profile. The organic soils are represented by many lithological types of soils: organic sand, mud, peat and gyttja. This group appears in the graph under the line marked along the value of $\mathrm{q}_{\mathrm{c}}<1-1.5 \mathrm{MPa}$. This value for Polish conditions may be considered as the border of "weak" soils (often considered for replacement or improvement). As it may be seen in the graph, clays and glacial clays (tills) are characterized by high variability. The interbeddings of more or less sandy or silty layers may be observed within clays and the group of clayey sands may be distinguished additionally. The influence of granulometry on $\mathrm{q}_{\mathrm{c}}$ value in sandy soils was confirmed.

\section{Determination of Density/Liquidity Index from CPTU}

CPTU soundings allow for determining the density/liquidity index of soils. The correlations presented in standards (PN-B-04452:2002) refer to cohesion and history of consolidation and do not take into consideration the litho-genetic factor. The research on interpretation of CPTU and DMT tests allowed for verifying existing correlations within each litho-genetic group. According to the standard (PN-81/B-03020) $\mathrm{I}_{\mathrm{L}}$ or $\mathrm{I}_{\mathrm{D}}$ determination together with the knowledge about the soil type allows accurate correlations with geotechnical parameters. On the basis of the genesis, four types of cohesive soils are distinguished in the Polish Standard (PN-81/B-03020). Non-cohesive soils are classified into three groups on the basis of particle size distribution. Having the information about the soil type and $\mathrm{I}_{\mathrm{L}}$ or $\mathrm{I}_{\mathrm{D}}$, geotechnical parameters $\left(\varphi^{\prime}, \mathrm{c}_{\mathrm{u}}, \mathrm{E}_{\mathrm{eod}}\right)$ may be read from the nomograms. These nomograms are the effect of experience and they are based on settlements measurements, triaxial tests and shear-box tests. The same rule may be found in the PN-EN 1997-1 standard. The "derived values" are concerned as values obtained from correlations.

The obtained correlation between $\mathrm{q}_{\mathrm{c}}\left(\right.$ or $\mathrm{q}_{\mathrm{t}}$ ) value for different types of soils (including their origin) and $I_{D}$ or $\mathrm{I}_{\mathrm{L}}\left(\right.$ or $\mathrm{I}_{\mathrm{C}}$ ) is presented in Figure 2. This graph is appropriate for the soils in Poland. Having the $I_{C}$ or $I_{D}$ values derived from $\mathrm{q}_{\mathrm{c}}$ the next step is to find correlation from Polish Standard or other graph with the values of $\mathrm{E}_{\mathrm{eod}}$ and then $\varphi$, and $\mathrm{c}_{\mathrm{u}}$.



Fig. 1. All results for different litho-genetic types of soils plotted on Schmertmann's nomogram (Source: Grant Nr 4 T07E 047 30, 2008) 


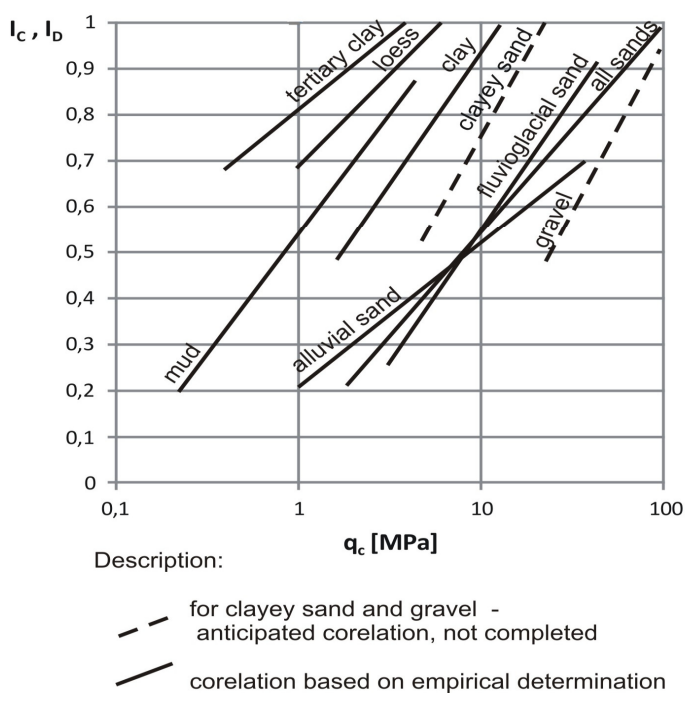

Fig. 2. Nomogram for $I_{C} / I_{D}$ determination on the basis of CPTU test for Polish soils

(Source: Grant Number 4 T07E 047 30, 2008)

\section{Calibration of CPTU/DMT Probes}

The Marchetti flat dilatometer is a device dedicated to determine the deformation parameters of soils. This is supported by the specificity of measurement itself (Marchetti 1980). Expanion of a steel membrane in the soil is a controlled displacement test, i.e. measurement of pressure at desired displacement. This allows for estimating the deformation modulus directly in the soil (in situ) which is the basis for determination of displacements of the designed structure.

Determining the magnitude of settlement and foreseeing such settlement is, especially for any structure designed in difficult geotechnical conditions, an element which is crucial to the determination of foundation method. Depending on the type and importance of the structure, the difference between shallow founding with the necessity to execute soil improvement or "avoidance" of the problem by deep foundations is small. For typical buildings (up to 11 storeys) the value of permissible settlement is $5 \mathrm{~cm}$ (as per National Annex to Eurocode 7), Polish Standard (PN-81/B-03020) allowed for $7 \mathrm{~cm}$. Direct evaluation of parameters (including moduli) of soil is possible only on the basis of test loads and by in situ methods.

The requirements of new European standards (PN-EN-1997-1 and PN-EN 1997-2) result in the necessity to carry out quantitative tests (mainly probing) when preparing the soil documentation. The correlations applied in practice between probing results and information on soil conditions of a founded structure require regional adjustments or adaptation to local conditions. This is very important because, determination of soilstructure interaction demands that properly determined parameters be used with a particular design method (Mitew-Czajewska 2015).
For the new types of static penetration probes (such as: CPTU with a piezocone or dilatometer) sufficiently good (regional) Polish correlations for interpretation of results have not been issued yet or they are not sufficiently verified. The literature data (including that specified in the annexes to Eurocode 7) obtained abroad in other soils are often unsatisfactory under Polish conditions and sometimes lead to incorrect conclusions (Godlewski 2013).

Worldwide experience (Monaco et al. 2006) indicates that DMT is highly useful in determination of soil deformation moduli. This method is reliable, provided that it is calibrated and validated (by other methods). In this case, the best method is to compare the settlement values measured at given structures or performance of test loads against the settlement values obtained from DMT. Comparison of settlement values measured at the structures with respect to those obtained by dilatometer and literature data (26 structures) (Monaco et al. 2006) and own observations (23 structures) (Godlewski 2015) is presented in Figure 3.

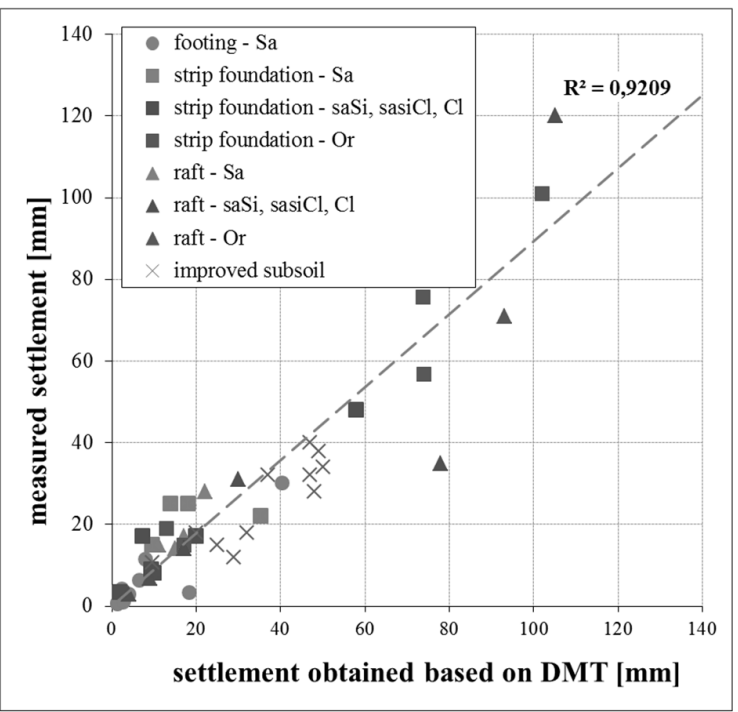

Fig. 3. Calibration curve obtained for Polish conditions relating to measurements from literature (Source: Godlewski 2015)

For a total of almost 50 structures, the type of foundation (pad, strip or slab foundation) and soils at the foundation level were indicated (sandy soil: Sa, cohesive: saSi, sasiCl, $\mathrm{Cl}$ and organic: Or). These are mainly typical residential and industrial buildings not exceeding 11 storeys with the exception of 2 road structures (abutment and embankment). Additionally a set of measurements for improved soil was added, wherein the dilatometer was used to determine the deformation modulus of the "composite" - soil and soil improvement elements (Dynamic Replacement / sand and gravel / Controlled Modulus Columns / concrete columns).The described set of buildings shows high correlation $\left(\mathrm{R}^{2}=\right.$ 0.92). It should be added that the given set of buildings was limited to structures with shallow foundation (including those on improved soil). For the purpose of 
evaluation and forecasting settlement, the dilatometer is a well-calibrated device for typical structures. In the cases of founding on very soft and organic soils in which the quality of drilling and collected samples is insufficient, only in situ probing allows for obtaining reliable parameters for design calculations.

\section{Correlation of CPTU/DMT results}

Dilatometric modulus as a reference value allows for calibration of CPT/CPTU results $\left(\mathrm{q}_{\mathrm{c}} \mathrm{i} \mathrm{R}_{\mathrm{f}}\right)$ with modulus values. The results obtained at each test site by means of CPTU and DMT soundings were compared. Dilatometer modulus $\left(\mathrm{E}_{\mathrm{D}}\right)$ were converted to confined modulus (M') by Marchetti method (Marchetti 1980).

In the first approach to data correlation, the graph of dilatometer modulus $\left(\mathrm{M}_{\mathrm{DMT}}\right)$ versus net cone resistance $\left(\mathrm{q}_{\mathrm{n}}\right.$, comprising vertical stress $\left.\mathrm{q}_{\mathrm{n}}=\mathrm{q}_{\mathrm{c}}-\sigma_{\mathrm{vo}}\right)$ was drawn. The method of linear regression allowed for obtaining the calculation coefficient for each test site. In the second step of analysis, the average value of calculation coefficient for each litho-genetic type of soil was determined. Example graphs show in Figures 4 and 5.

The best validation was obtained for river sands and hollow silts $\left(\mathrm{R}^{2} \geq 0.6\right)$. In case of glacial clays or organic (special muds) deposits the correlation was unsatisfactory $\left(\mathrm{R}^{2} \leq 0.3\right)$. This is due to specific character of these soils. Glacial clays are a type of mixed material: from silty sands to clays, with large natural variability. The same situation is in the case of organic deposits.

Mean values obtained from correlation for all analysed types of soils, are shown in Table 1. It was compared with selected (most popular from primary literature) experience of different Author's.

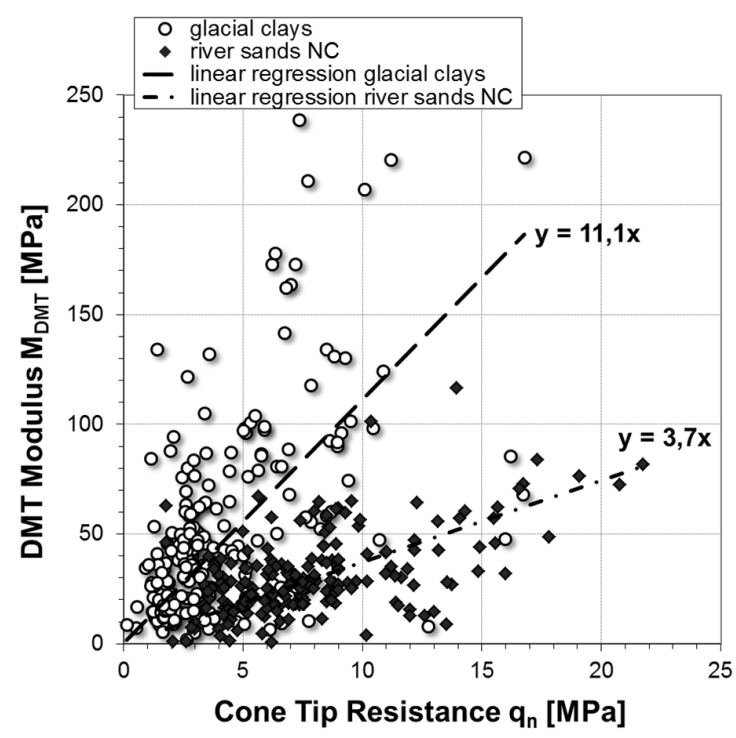

Fig. 4. M $\mathrm{DMT}_{\text {versus }} \mathrm{q}_{\mathrm{n}}$ for glacial clays and rivera sands

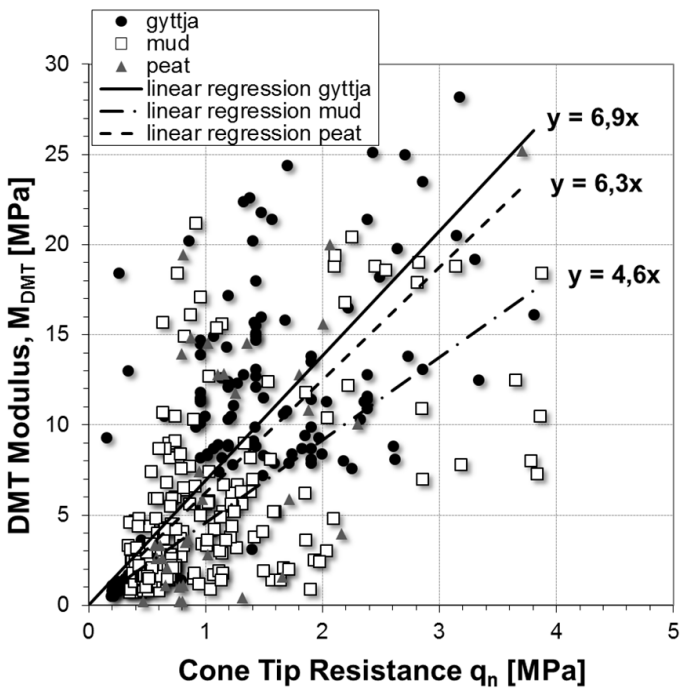

Fig. 5. MDMT versus $\mathrm{q}_{\mathrm{n}}$ for all anylased organic soils

\section{Discussions}

Of course the authors realize that given values require consideration of additional factors affecting poor correlation parameters. However, given the coefficients for each soils type (empirical cone factor " $\alpha$ ") very well characterised by specificities of Polish ground conditions. This is particularly evident in the case of glacial clay (tills) or tertiary clay, which is "very strong" soils (rated by soil consistency as hard to extremaly hard). In this case, the values are several times higher than proposed in the literature.

In Polish practice in the interpretation of CPTU tests three factor's are most commonly used: $\alpha=15$ for non-cohesive soils, $\alpha=8$ for cohesive soils and $\alpha<1.5$ for organic soils. Sometimes, significant differences clearly indicate that it is not correct approach in all cases.

Presented method of interpretation is very simplified (Sanglerat 1972; Mayne 2001). In literature (Tanaka, H., Tanaka, M. 1998; Sikora 2006) are known to have more complex methods of determining the constrained modulus value from CPTU tests - with regard to overburden stress $\left(\sigma_{\mathrm{v} 0}\right)$ or stress history (OCR). But this method, (based on general formula described by Sanglerat) is still more popular in geotechnical practice.

Presented results relate to large statistic test and have high statistical value because about 3000 results were used for the analysis.

Constrained modulus (M) taken for presented empirical cone factor $(\alpha)$ applies to range of horizontal stress from 100 to $400 \mathrm{kPa}$.

The next step included the correlation determination for classifying parameters for each type of sounding. The classification value $\mathrm{R}_{\mathrm{f}}$ (or Friction Ratio FR) from CPTU and material index $\mathrm{I}_{\mathrm{DMT}}$ (in publications $I_{D}$, it should not be considered as density index) from DMT were taken into correlations. Both the material index from DMT and sleeve friction from CPTU refers to particle size distribution. 
Table 1. The obtained coefficients on the basis of charts - proposition of empirical cone factors $(\alpha)$ to estimate modulous value $\left(\mathrm{E}_{\mathrm{eod}}\right)$ for Polish grounds conditions, versus literature

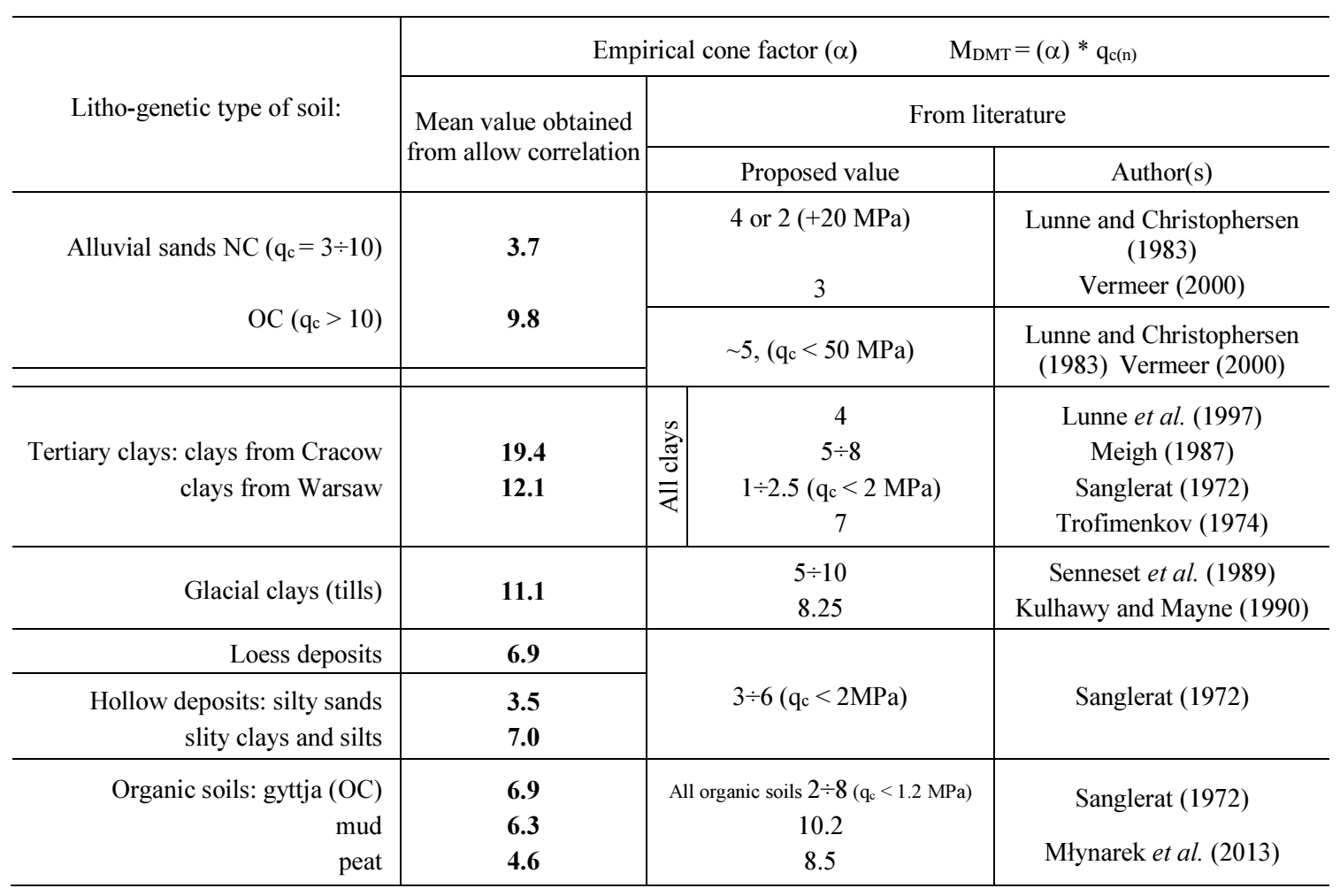

After that, on the basis of CPTU test results, the values of the modulus will be determine, using the same calculations as for DMT (base on $\mathrm{E}_{\mathrm{D}}$ and $\mathrm{I}_{\mathrm{D}}$ formulas). According to Marchetti instruction (Marchetti 1980) the modulus may be obtained having $R_{M}$ coefficient $\left(R_{M}=\right.$ $\left.M^{\prime} / E_{D}\right)$, which is calculated from material index $I_{D}$ and vertical strain coefficient $\mathrm{K}_{\mathrm{D}}$. This will allow to evaluate $M$ value from CPTU using DMT formulas.

These relationships for different types of soils could help make some validation of CPTU method. Thus, improving the reliability of the given correlation so far.

\section{Conclusions}

The development of interpretation methods of soundings is based mainly on statistical correlations which demand huge set of measurements. The examples of these sets are in Polish Standards (PN-81/B-03020), geological and engineering atlas of Warsaw and ITB guidelines. The comparison of the results gave local correlations or allowed adjusting the classification from the literature to local conditions.

All existing nomograms may be used only if the appropriate (according to standards) penetrator is used according to particular procedure. The Eurocode 7 (PNEN-1997-1 and PN-EN 1997-2) need the National Annexes preparation - taking account for e.g. the local correlation to estimate soils parameters. The correlations presented in the article are the examples which may be used in the Polish practice. From the scientific point of view, the obtained correlations may be compared to the data from literature as a background.

It should be underlined that presented (and planned) analyses support the Eurocode 7 implementation process. The main goal of these analyses was intercorrelation between CPTU and DMT tests for Polish typical soils. However, some issues still need to be supplemented: loess, gravels, sand and gravel mixtures should be added to the database and overconsolidation and cementation processes should be taken into consideration for sands as well as anisotrophy of clays. These factors probably caused high scatter of the results.

Because of the article size limit not all issues have been presented. The authors give only information about the problem which needs further investigations.

\section{Acknowledgements}

The authors wish to express their thanks to the all anonymous reviewers for constructive criticism and comments on the manuscript.

\section{Funding}

Part of this work was supported by the funds for science in the years 2006-2008 as a Research Project: "Regional correlations of geotechnical parameters on the basis of soundings, laboratory tests and settlements measurements" supported by KBN [grant number 4 T07E 047 30]. 


\section{References}

Bałachowski, L.; Kozak, P.; Kurek, N. 2008. Intercorrelation between CPTU-DMT test for sands on the Baltic coast, in Z. Młynarek, Z. Sikora, E. Dembicki (Eds.). Proceedings of the $11^{\text {th }}$ Baltic Sea Geotechnical Conference "Geotechnics in Marintime Engineering”, 15-18 September 2008, Gdańsk, Poland. 1: 359-366. Gdańsk: Printing-Office MISIURO.

Godlewski, T. 2013. Interpretacja badań polowych a Eurokod 7. Acta Scientiarum Polonorum, ArchitekturaBudownictwo 12(3): 61-72.

Godlewski, T. 2015. Practical use of the dilatometer tests some case studies from Poland, in Proc. of The $3^{\text {rd }}$ International Conference on the Flat Dilatometer DMT'15, 15-17 June 2015, Rome, Italy, 99-106.

Kulhawy, F. H.; Mayne, P. H. 1990. Manual on estimatingsoil properties for foundation design. Electric Power Research Institute, EPRI.

Lunne, T.; Christophersen, H. P. 1983. Interpretation of cone penetrometer data for offshore sands, in Proceedings of the Offshore Technology Conference, 2-5 May 1983, Houston, Texas. Paper No 4464. http://dx.doi.org/10.4043/4464-MS

Lunne, T.; Robertson, P.; Powell, J. 1997. Cone Penetration Testing in Geotechnical Practise. London: Blackie Academic and Professional.

Marchetti, S. 1980. in situ tests by flat dilatometer, Journal of the Geotechnical Engineering Division, ASCE 106(GT3): 299-321.

Mayne, P. W. 2001. Stress-strain-strenght-flow parameters from enhanced in-situ tests, in Proc. of International Conference on In Situ Measurement of Soil Properties \& Case Histories (In Situ 2001), 21-24 May 2001, Bali, Indonesia, 27-48.

Meigh, A. C. 1987. Cone penetration testing - methods and interpretation. CIRIA, London. $141 \mathrm{p}$.

Mitew-Czajewska, M. 2015. Geotechnical investigation and static analysis of deep excavation walls - a case study of metro station construction in Warsaw, Annals of Warsaw University of Life Sciences - SGGW. Land Reclamation 47(2): 163-170.

http://dx.doi.org/10.1515/sggw-2015-0022

Młynarek, Z.; Wierzbicki, J.; Long, M. 2008. Factors affecting CPTU and DMT characteristics in organic soils, in Z. Młynarek, Z. Sikora, E. Dembicki (Eds.). Proc. of $11^{\text {th }}$ Baltic Sea Geotechnical Conference, "Geotechnics in Marintime Engineering”, 15-18 September 2008, Gdańsk, Poland, 1: 407-417. Gdańsk: Printing-Office MISIURO.
Młynarek, Z.; Stefaniak, K.; Wierzbicki, J. 2013. Evaluation of deformation parameters of organic subsoil by means of CPTU, DMT, SDMT, Architecture Civil Engineering Environment 6(4): 51-58.

Monaco, P.; Totani, G.; Calabrese, M. 2006. DMT - predicted vs observed settlements: a review of the available experience, in Proc. from the Second International Flat Dilatometer Conference, 2-5 April 2006, Washington D.C., 275-280.

PN-B-04452:2002. Geotechnika - Badania polowe. Polish Standard, 2002.

PN-81/B-03020. Grunty budowlane. Posadowienie bezpośrednie budowli. Obliczenia statyczne $i$ projektowanie. Polish Standard.

PN-EN 1997-1. Eurokod 7 - Geotechnical Design - Part 1 General rules. European/Polish Standard, 2008.

PN-EN 1997-2. Eurokod 7 - Geotechnical Design - Part 2 Ground investigation and testing. European/Polish Standard, 2008.

Rabarijoely, S.; Garbulewski, K. 2013. Simultaneous interpretation of CPT/DMT tests to ground characterization, in Proceedings of the $18^{\text {th }}$ International Conference on Soil Mechanics and Geotechnical Engineering, 2-6 September 2013, Paris, France, 1: 1337-1340.

Research Project 4 T07E 047 30. 2008. Zależności regionalne parametrów geotechnicznych na podstawie sondowań, badań laboratoryjnych i pomiarów osiadań. Funding by Komitet Badań Naukowych przy Ministerstwie Edukacji i Nauki, ITB/BRI, Warsaw.

Sanglerat, G. 1972. The penetrometr and soil exploration. Amsterdam: Elsevier.

Senneset, K.; Sandven, R.; Janbu, N. 1989. The evaluation of soil parameters from piezocone tests, Transportation Research Record 1235: 24-37.

Sikora, Z. 2006. Sondowanie statyczne - metody $i$ zastosowanie $w$ geoinżynierii. Warszawa: Wyd. nauktech.

Schmertmann, J. H., et al. 1986. CPT/DMT quality control of ground modification at a power plant, in Proc. In situ ' 86 ASCE Spec. Conference, 23-25 June 1986, Virginia Tech, Blacksburg, VA, 985-1001.

Tanaka, H.; Tanaka, M. 1998. Characterization of sandy soils using CPT and DMT, Soils and Foundations 38(3): 5565. http://dx.doi.org/10.3208/sandf.38.3_55

Trofimenkov, J. G. 1974. Penetration Test in URSS - State-of the Art. Report, in Proceedings of the European Symposium on Penetration Testing, 5-7 June 1974, Stockholm, Sweden, 1: 147-154.

Vermeer, P. A. 2000. Column Vermeer. Plaxis Bulletin n ${ }^{\circ}$, July 2000 . 